EWELINA KONIECZNA

ORCID 0000-0002-8042-3956

Uniwersytet Ślaski w Katowicach

\title{
MEDIA SPOŁECZNOŚCIOWE W RĘKACH MŁODYCH LUDZI
}

\begin{abstract}
Aвstract. Konieczna Ewelina, Media społecznościowe w rękach młodych ludzi [Social Media in the Hands of Young People]. Studia Edukacyjne nr 58, 2020, Poznań 2020, pp. 247-262. Adam Mickiewicz University Press. ISSN 1233-6688. DOI: 10.14746/se.2020.58.13

Popular media culture has been a vital resource through which youth generations have defined themselves, their desires, and their hopes and dreams. This continues to be reflected in the dynamic ways that the youth are using digital media to shape their everyday lives. As a result, young people are constantly creative; they acquire new skills and make up groups and communities in the media culture. The purpose of the reflections in the article is a look at the media practices of young people and an attempt to find an answer to the question how the young generation uses social media for communication and participation in culture and how social media change media culture.
\end{abstract}

Key words: social media, media education, participation in culture

\section{Wprowadzenie}

Problematyka młodzieży i mediów, szeroko dyskutowana przez pedagogów medioznawców, czy socjologów, co jakiś czas powraca na listę ważnych zagadnień związanych z rozwojem technologii cyfrowych oraz przeobrażeń społecznych i cywilizacyjnych. Jest to w pełni zrozumiałe, bo aktualność problemu, tak jak i rozwój mediów, powstawanie nowych, a także zmiany $\mathrm{w}$ komunikowaniu z tym związane wymagają stałej refleksji badawczej, przyglądania się nowym zjawiskom i poznawania mechanizmów wzajemnych relacji. Pytanie o to, co ludzie robią z mediami i co media robią z ludźmi pozostaje ciągle aktualne, bo odpowiedzi na nie zmieniają się i będą się zmieniać wraz z rozwojem technologii. Pod wpływem mediów cyfrowych przewartościowują się nie tylko sposoby komunikowania ludzi, ale także formy uczestnictwa w kulturze, czy programy edukacyjne. Zmie- 
nia się też zakres edukacji medialnej ${ }^{1}$, która jako kluczowy obszar rozwoju kompetencji cywilizacyjnych powinna być częścią polityki oświatowej i systemu edukacji na wszystkich etapach kształcenia, również w edukacji ustawicznej (Long Life Learning), stając się narzędziem służącym wyrównywaniu szans edukacyjnych i zapobiegania wykluczeniu cyfrowemu². Współczesna edukacja medialna ${ }^{3}$ wymaga skupienia się nie tyle na rozwijaniu kompetencji technologicznych uczniów, bo o to potrafią zadbać sami, czy niekorzystnym wpływie mediów, ale na kształtowaniu kompetencji medialnych pozwalających na korzystanie z zasobów kulturalnych oraz na budowaniu kompetencji intertekstualnych przez kontakt $\mathrm{z}$ mediami. Tak rozumiane kompetencje medialne "mają dziś fundamentalne znaczenie w transmisji dorobku kulturalnego ludzkości" ${ }^{4}$. Celem moich rozważań jest przyjrzenie się praktykom medialnym młodych ludzi i próba znalezienia odpowiedzi na pytanie: jak młode pokolenie wykorzystuje media cyfrowe do komunikacji oraz uczestnictwa w kulturze oraz jak media społecznościowe zmieniają kulturę medialną. Omawiane zagadnienia są wstępem do planowanego szerszego projektu badawczego, zainicjowanego $\mathrm{w}$ ramach realizacji przedmiotu edukacja medialna na kierunku animacja społeczno-kulturalna z edukacją kulturalną, na studiach pierwszego stopnia prowadzonych w roku akademickim 2018/2019 na Wydziale Etnologii i Nauk o Edukacji Uniwersytetu Śląskiego w Katowicach.

\section{Młodzi i media}

W 2010 roku opublikowany został raport pt. „Młodzi i media. Nowe media a uczestnictwo w kulturze" ${ }^{2}$, będący efektem pracy zespołu badaczy Centrum Badań nad Kulturą Popularną SWPS (obecnie Uniwersytetu SWPS), składającego się z medioznawców, socjologów i antropologów. Celem badań było przede wszystkim przyjrzenie się, jak młodzi ludzie wykorzystują dostępne

${ }^{1}$ Zob. A. Ogonowska, Edukacja medialna. Klucz do rozumienia społecznej rzeczywistości, Kraków 2003; taże, Telewizja w edukacji medialnej, Kraków 2009; taże, Wspótczesna edukacja medialna: teoria i rzeczywistość, Kraków 2013; Edukacja medialna w dobie wspótczesnych zmian kulturowych, społecznych i technologicznych, red. A. Ogonowska, G. Ptaszek, Kraków 2015.

${ }^{2}$ Edukacja medialna jako kapitał społeczno-kulturowy w społeczeństwach wiedzy. Wnioski i rekomendacje po I Kongresie Edukacji Medialnej (Kraków 25-26 września 2014), [w:] Edukacja medialna $w$ dobie wspótczesnych zmian, s. 225.

${ }^{3}$ S.R. Poyntz, J. Pedri, Youth and Media Culture, Oxford 2018, http://oxfordre.com/education/view/10.1093/acrefore/9780190264093.001.0001/acrefore-9780190264093-e-75 [dostęp: 10.12.2018]

${ }^{4}$ M. Lisowka-Magdziarz, Edukacja medialna w kontekście praktyk twórczych i interpretacyjnych, [w:] Edukacja medialna w dobie wspótczesnych zmian, s. 131.

${ }^{5}$ M. Filiciak i in., Młodzi i media. Nowe media a uczestnictwo w kulturze. Raport Centrum Badań nad Kulturą Popularną SWPS, Warszawa 2010. 
technologie w codziennym życiu oraz jak te praktyki zmieniają się w czasie. Badaczy interesowały zmiany dokonujące się w obrębie obiegu treści kultury, szczególnie w kontekście jej przemian z kultury analogowej w cyfrową i globalną, jak również tworzenie się nowych wspólnot i nowej podmiotowości. Wyniki tych badań, wnikliwie opracowane i zaprezentowane w raporcie, dały interesujący obraz przemian form uczestnictwa w kulturze i środowiska kulturowego w pierwszej dekadzie XXI wieku, wskazując na coraz większą rolę odbiorców - twórców/wytwórców komunikatów medialnych. Wojciech Burszta tak podsumowuje wyniki badań:

\begin{abstract}
jesteśmy świadkami wybuchu supernowej kultury. Rewolucja ta dotyczy przede wszystkim tożsamości kulturowej młodych Polaków. Tożsamość podlega zmianom w kierunku jej większej elastyczności i autorefleksyjności, indywidualizuje się i autonomizuje względem tradycyjnych wyznaczników "przenikających”. Kultura to coraz częściej sfera wyborów czynionych poza jakimikolwiek układami społecznymi, nie tyle kultura identyfikowana $\mathrm{z}$ instytucjami, ile raczej z dostępnymi treściami, które towarzyszą ludziom 24 godziny na dobę.
\end{abstract}

Kolejna dekada XXI wieku zbliża się do końca, dekada, w której zawrotną karierę zrobiło mobilne urządzenie multimedialne, czyli smartfon - połączenie telefonu i przenośnego komputera, pozwalające użytkownikom kontaktować się z rozmaitymi treściami w każdej chwili i niemal w każdym miejscu. Badania opisane $\mathrm{w}$ raporcie prowadzono prawie dziesięć lat temu, dlatego zasadne wydaje się ponowne przyjrzenie się codziennym praktykom użytkowników mediów i sprawdzenie, jak wykorzystują nowe, mobilne urządzenie, które zrewolucjonizowało rynek telefonów komórkowych i sposobu komunikacji. Jeszcze niedawno dotykowy ekran i rozbudowane aplikacje były czymś wyjątkowym, obecnie trudno byłoby zrezygnować z rozmaitych kanałów komunikacji, które spopularyzowały smartfony, łączące funkcje telefonu, poczty elektronicznej, przeglądarki, nawigacji GPS, a także aparatu fotograficznego, kamery i centrum rozrywki. Smartfony dla większości ludzi, nie tylko młodych, to codzienność; rozpoczynają dzień od wyłączenia budzika, sprawdzenia powiadomień na portalach społecznościowych i komunikatorach, przeczytania poczty i wiadomości.

\title{
Bring Your Own Device
}

Smartfony stają się przedmiotem zainteresowań badawczych, refleksji naukowej ${ }^{7}$, czy praktyki edukacyjnej. W studium Smartfon jako osobiste narze-

${ }^{6}$ Tamże, s. 143.

7 Por. A. Broch, Smartfon w klasie: od zabawki do narzędzia edukacyjnego, Studia Edukacyjne, 2018, 48, s. 335-347. 
dzie edukacyjne ucznia. Analiza i rekomendacje ekspertów Sieci Edukacji Cyfrowej KOMET@, opublikowanym w październiku 2018 roku, czytamy:

Smartfonem posługuje się w Polsce zdecydowana większość dzieci i młodzieży w wieku 7-14 lat - 83,6 procent (UKE, 2017). Jest on dla tej grupy wiekowej podstawowym narzędziem osobistego kontaktu i komunikowania się ze światem: tak w relacjach z ludźmi, jak i w korzystaniu z platform i aplikacji internetowych. Ponad połowa (53,1 proc.) dzieci korzysta z oferty telefonii komórkowej na kartę. Operatorzy telekomunikacji raportowali wielokrotnie, iż smartfon stał się jednym z podstawowych zakupów z okazji urodzin, „Pierwszej Komunii”, czy innych wydarzeń jubileuszowych ucznia. Smartfon to killing device 2 dekady XXI wieku'.

Analizy zawarte $\mathrm{w}$ dokumencie skupiają się na wprowadzeniu modelu BYOD (Bring Your Own Device) do edukacji szkolnej, jako jednego z elementów modernizacji dydaktycznej polskiej oświaty. W opinii autorów, niezbędna jest jak najszybsza cyfrowa modernizacja polskiego systemu oświaty, by szkoła w pełni mogła korzystać z cyfrowych zasobów i platform edukacyjnych, w czym mogą pomóc własne urządzenia mobilne uczniów. Propozycje i modele wykorzystania zasobów oraz platform cyfrowych w edukacji omówiono w kilku głównych obszarach (podejście BYOD, cyfrowe zasoby edukacyjne, partnerstwo nauczyciel-uczeń, kontekst perspektywy konstruktywistycznej, kwadrat funkcjonalny dydaktyki cyfrowej, model u-learningowy, cyberbezpieczeństwo ucznia i szkoły). Zawarte w publikacji rekomendacje transformacyjne skierowane są do czterech grup biorących udział w procesie edukacji: Ministerstwa Edukacji Narodowej, samorządów, dyrektorów szkół i nauczycieli. Autorzy dokumentu przekonują:

Szkoła, w której wprowadzony zostanie skutecznie model BYOD, staje się nowoczesnym, cyfrowym środowiskiem uczenia (się), odpowiadającym na oczekiwania uczniów. Umożliwia bowiem nieograniczone, zależne tylko od pomysłowości oraz rzeczywistych potrzeb nauczycieli i uczniów korzystanie z zasobów sieci, a także gwarantuje interakcje drogą elektroniczną na lekcjach każdego przedmiotu (...) Zastosowanie smartfonów w szkole to jeden z najlepszych sposobów na upodmiotowienie uczniów. Uczniowie często mają poczucie, że kompetencje, które posiadają są lekceważone. Że ich biegłość w obsłudze aplikacji nie ma dla nikogo znaczenia. Ich zainteresowania są piętnowane. Zarzuca im się brak motywacji. Tymczasem posiadają zasoby, którymi chcą się pochwalić9

Przyglądając się praktyce edukacyjnej i wynikom badań, zauważa się nikłe zainteresowanie wykorzystaniem smartfonów w edukacji, przede wszyst-

${ }^{8}$ Smartfon jako osobiste narzędzie edukacyjne ucznia. Analiza i rekomendacje ekspertów Sieci Edukacji Cyfrowej KOMET@, Warszawa 2018. http:/ / presscafe.eu/assets/img/smartfon_w_szkole. pdf [dostęp:03.12.2018]

9 Tamże. 
kim ze względu na opór nauczycieli przed nową technologią. Spowodowane jest to przede wszystkim ich lękiem, że nie nadążają za zdigitalizowanymi uczniami w dziedzinie nowych mediów. Póki co, nauczyciele (cyfrowi imigranci) nie są gotowi na zamianę miejsc oraz przełamanie barier i nie chcą się uczyć od swych uczniów ${ }^{10}$.

\section{Uczestnictwo w kulturze medialnej}

Pod wpływem nowych mediów zmieniają się sposoby uczestnictwa w życiu kulturalnym, co przyczynia się do zróżnicowania zainteresowań kulturalnych oraz "rozproszenia” publiczności. Wynikiem tych przeobrażeń jest wynikający z procesów globalizacyjnych zanik kulturowych granic oraz łatwość dostępu do tekstów kultury ${ }^{11}$. W badaniach pedagogicznych zagadnienie uczestnictwa w kulturze analizowane jest zwykle na podstawie badań ilościowych, które dominowały w Polsce w latach 70. i 80. XX wieku. Zdaniem Witolda Jakubowskiego, prowadzenie badań nad uczestnictwem w kulturze oparte na paradygmacie pozytywistycznym nie pozwala na poznanie sposobu odbioru współczesnych tekstów kultury należących często do kultury popularnej. Powołując się na innych autorów (Johna Fiske, Wiesława Godzica, Mateusza Halawę $e^{12}$ ), autor przekonuje, że odbiór tekstów kultury popularnej jest procesem aktywnym, angażującym odbiorcę, który podejmuje dialog i grę z przekazem. Jakubowski zwraca uwagę na konieczność przełamania negatywnych stereotypów dotyczących mediów elektronicznych i podejmowania we współczesnej debacie pedagogicznej refleksji i badań, obejmujących ich edukacyjny potencjał. Autor postuluje o wykorzystanie w badaniach pedagogicznych interdyscyplinarnego podejścia opartego na teoretycznym i metodologicznym dorobku humanistyki (kulturoznawstwa, filmoznawstwa, medioznawstwa, studiów kulturowych) ${ }^{13}$.

Marek Krajewski przedstawia interesującą propozycję rozumienia kategorii uczestnictwo w kulturze oraz badania zjawisk, które występują pod tą nazwą $^{14}$. Uczestnictwo w kulturze badacz rozumie jako

\footnotetext{
${ }^{10}$ A. Broch, Smartfon w klasie, s. 345.

${ }^{11}$ Zob. B. Fatyga, Rekonstrukcja sensu kategorii uczestnictwo w kulturze, [w:] Praktyki kulturalne Polaków, red. R. Drozdowski, B. Fatyga, M. Filiciak, M. Krajewski, T. Szlendak, Toruń 2014.

${ }_{12}$ Por. J. Fiske, Zrozumieć kulturę popularna, Kraków 2010; W. Godzic, Oglądanie i inne przyjemności kultury popularnej, Kraków 1996; M. Halawa, Życie codzienne z telewizorem, Warszawa 2006.

${ }^{13}$ W. Jakubowski, Aktywność kulturalna w świecie popkultury, Studia Edukacyjne, 2010, 11, s. $29-44$.

${ }^{14}$ Por. M. Krajewski, W kierunku relacyjnej koncepcji uczestnictwa w kulturze, Kultura i Społeczeństwo, 2013, 1; tenże, Uczestnictwo w kulturze, [w:] Praktyki kulturalne Polaków.
} 
proces włączenia danego elementu (jednostki, grupy, ale też przedmiotu) w pewną sytuację uregulowaną kulturowo, a więc proces zachodzący dzięki językowi, normom i wartościom, narzędziom i przedmiotom stworzonym przez człowieka. Kategoria uczestnictwo w kulturze odnosi się przede wszystkim do faktu bycia aktywnym składnikiem relacji konstytuujących określoną sytuację, a więc oznacza też wpływanie na stosunki zachodzące między elementami, które ją tworzą ${ }^{15}$.

W takim rozumieniu uczestnictwo w kulturze nie polega wyłącznie na partycypacji w życiu kulturalnym (chodzeniu do kina, muzeum i na koncerty), ale dotyczy każdej sytuacji, w której człowiek staje się uczestnikiem relacji ustanawiających określoną zbiorowość i odpowiedzialnych za jej trwanie oraz powtarzanie. Tak rozumiane uczestnictwo w kulturze jest procesem włączania w życie społeczne pewnej zbiorowości, a także obarczenie jej współodpowiedzialnością za jej specyfikę oraz potencjalne przeobrażanie. Zdaniem Krajewskiego, badania uczestnictwa w kulturze powinny dotyczyć „analizy natury stosunków, tworzących tę konfigurację, a także sposobów ich praktykowania, nawiązywania, zrywania, przekształcania, podtrzymywania"16. Celem analiz uczestnictwa w kulturze określonej zbiorowości jest nie tylko

odtworzenie genealogii tej kultury czy wskazanie na rolę, jaką odgrywają w jej tworzeniu i podtrzymywaniu poszczególne elementy, ale również w istocie badanie tego, jak przebiega proces uspołeczniania, a więc wiązania ze sobą elementów składających się na daną rzeczywistość ${ }^{17}$.

Rzeczywistością młodych ludzi jest, służąca przede wszystkim rozrywce, zmediatyzowana kultura, która przyciąga swą atrakcyjnością, łatwością odbioru i uczestnictwa w niej. Jak pisze Małgorzata Lisowska-Magdziarz:

W medialnej przestrzeni znajduje się miejsce dla wszystkich materiałów kulturalnych, a rozmiary połączonych ze sobą nisz i kultur gustu o specyficznych zainteresowaniach czy elitarnych upodobaniach są niemal równe rozmiarom mainstreamu. Każdy odnajdzie tu coś dla siebie, pod warunkiem, że potrafi szukać; każdy może się włączyć w dystrybucję materiału kulturalnego, pod warunkiem, że potrafi użyć do tego dostępnych narzędzi i środków wyrazu; możliwe jest rozpowszechnienie i upowszechnianie każdego gustu, stylu, tematu, gatunku i nurtu kultury, pod warunkiem, że zostanie on odpowiednio usytuowany, wyeksponowany, poddany procesom zbiorowego wytwarzania i redystrybucji wiedzy ${ }^{18}$.

Użytkownicy mediów mają niełatwe zadanie, bo wielość treści - tekstów i obrazów - oraz łatwość dostępu do nich skutkuje rozproszeniem informa-

${ }^{15}$ M. Krajewski, Uczestnictwo w kulturze, s. 17.

16 Tamże.

17 Tamże, s. 18.

${ }^{18}$ M. Lisowska-Magdziarz, Edukacja medialna w kontekście praktyk twórczych $i$ interpretacyjnych, [w:] Edukacja medialna w dobie wspótczesnych zmian, s. 137-138. 
cji i wiedzy. Lisowska-Magdziarz zwraca uwagę na autonomiczny charakter doświadczeń medialnych młodych ludzi, którzy za pośrednictwem dostępnych narzędzi, także tych samodzielnie stworzonych, kształtują swój medialny repertuar oparty na zmienności, doraźności, pozwalający na błyskawiczną wymianę, przekształcanie i reinterpretowanie materiału kulturalnego. Autorka próbując poznać zasoby intertekstualne dwudziestolatków, zwróciła uwagę na rozproszenie ich doświadczenia kulturalnego, które ma charakter fragmentaryczny, nieciągły i w nikłym stopniu nawiązujący do zasobów starszych pokoleń. Doświadczenia kulturalne kształtowane są raczej na poziomie rozmaitych wspólnot: towarzyskich, fanowskich, konsumenckich, zabawowych, politycznych, a nie generacyjnych ${ }^{19}$.

\section{Codzienna aktywność medialna młodych ludzi}

Pora podjąć próbę odpowiedzi na pytanie: jak młode pokolenie wykorzystuje media elektroniczne do komunikacji i uczestnictwa w kulturze oraz jak media społecznościowe zmieniają kulturę medialną? Do przeprowadzenia badań, które stanowią zalążek przyszłego szerszego projektu badawczego, zostali zaangażowani studenci kierunku animacja społeczno-kulturalna $\mathrm{z}$ edukacją kulturalną, $\mathrm{w}$ ramach zajęć $\mathrm{z}$ przedmiotu edukacja medialna. Moduł edukacja medialna obejmuje zagadnienia pedagogiki medialnej i audiowizualnych uwarunkowań współczesnej kultury. Edukacja medialna rozważana jest w kontekście edukacji kulturalnej, gdzie media są nośnikiem kultury i mogą być wykorzystywane do tworzenia i odbioru dóbr kultury. Celem modułu jest przygotowanie studenta do projektowania i prowadzenia zajęć z zakresu edukacji medialnej $\mathrm{w}$ instytucjach kultury (kinach, mediatekach, bibliotekach, domach kultury), środowiskach społeczno-wychowawczych i różnych grupach wiekowych, wykształcenie umiejętności świadomego i krytycznego odbioru komunikatów medialnych oraz znajomości roli i znaczenia mediów w działalności kulturotwórczej człowieka.

Jednym z celów zajęć konwersatoryjnych jest poznanie doświadczeń medialnych, rodzajów aktywności medialnej oraz uwarunkowań uczestnictwa w kulturze odbiorców mediów, zwłaszcza młodych. Zadaniem studentów było wspólne stworzenie scenariusza wywiadu, następnie przeprowadzenie wywiadu z wybraną osobą oraz analiza i prezentacja uzyskanych wyników na forum grupy (grupa liczyła dwanaście osób). Wywiad miał charakter nieustrukturyzowany, pogłębiony. Do badań wykorzystana została metoda badań jakościowych, opierająca się na nastawieniu, które cechuje subiektyw-

19 Tamże, s. 139. 
ność oraz empatia badacza w stosunku do osoby badanej. Wnioski z badań dotyczą jedynie tej próby oraz określonego czasu i miejsca, w którym przeprowadzono badania. Według Johna W. Creswella,

badanie jakościowe oznacza analizowanie i interpretowanie znaczeń, jakie jednostki lub grupy przypisują problemom z zakresu nauk społecznych i nauk o człowieku. Proces badawczy obejmuje wyłanianie nowych pytań i procedur w toku badania, gromadzenie danych w warunkach współuczestnictwa, indukcyjną analizę danych od szczegółu do ogółu oraz interpretację znaczenia danych. Końcowy raport pisemny ma strukturę elastyczną. Badacze, którzy wybierają to ujęcie, starają się zachowywać styl indukcyjny, kładą nacisk na indywidualne interpretacje i dają wyraz złożoności sytuacji ${ }^{20}$.

Studenci wybierali do badań dobrze znane osoby z własnego środowiska, zwykle rówieśników w wieku 21-23 lat. Projektując scenariusz wywiadu, opierali się na własnym doświadczeniu, zainteresowaniach i aktywności w mediach, głównie społecznościowych. Warto podkreślić duże, osobiste zaangażowanie studentów $\mathrm{w}$ wykonanie zadania, tak na etapie projektowania wywiadu, jak i prezentowania uzyskanych wyników. Wprowadzenie do programu zajęć aktywności badawczej, związanej bezpośrednio z ich pokoleniowym i codziennym doświadczeniem, stało się bodźcem do pogłębionej dyskusji, wymiany poglądów i opinii. Celem ćwiczenia było nie tylko pozyskanie wiedzy na temat doświadczeń innych użytkowników mediów, ale również refleksyjne nastawienie do podjętego w badaniach problemu, służące zdobyciu samoświadomości, dotyczącej własnej aktywności w mediach oraz krytycznego do niej stosunku. Scenariusz wywiadu zawierał zagadnienia, które należało poruszyć $\mathrm{w}$ rozmowie, czasem pogłębić i zadać dodatkowe pytania, aby uzyskać wyczerpujące i szczere odpowiedzi. Główne zagadnienia poruszane $w$ rozmowie obejmowały:

- korzystanie z urządzeń elektronicznych i rodzaje aktywności w mediach społecznościowych,

- udostępnianie materiałów w Sieci,

- tworzenie własnych treści oraz ich publikowanie w Sieci,

- prywatność w Sieci i jej ochrona,

- uczestnictwo w kulturze i jego uwarunkowania,

- problem praw autorskich w mediach,

- konstruowanie tożsamości w mediach i przez media,

- budowanie grup i wspólnot,

- sposoby weryfikacji wiarygodności informacji dostępnych w mediach,

- zagrożenia i korzyści jakie niesie korzystanie z mediów elektronicznych.

${ }^{20}$ J.W. Creswell, Projektowanie badań naukowych, Metody jakościowe, ilościowe i mieszane, przekł. J. Gilewicz, Kraków 2013, s. 30. 
W celu ułatwienia badanym formułowania wypowiedzi, studenci wspólnie stworzyli listę pytań pomocniczych do scenariusza wywiadu, które doprecyzowały poruszane zagadnienia i stanowiły wsparcie zarówno dla badanych, jak i młodych badaczy. Zadaniem studentów było również przygotowanie wniosków ze swoich badań w formie pisemnej. Poniżej, jako egzemplifikację wykonanej przez studentów pracy, zamieściłam opracowany przez jedną ze studentek wywiad z 21-letnią kobietą, studiującą $\mathrm{w}$ mieście liczącym ponad 150 tysięcy mieszkańców, ale mieszkającą na stałe na wsi (zapis oryginalny).

Natalia spędza dokładnie 3h 32 minuty (według licznika na jej telefonie) w mediach społecznościowych + około $2 h$ na seriale/filmy. Jest biernym użytkownikiem. Sama uważa siebie za uzależniona, ponieważ nie jest w stanie wytrzymać więcej niż godzinę bez telefonu komórkowego przy sobie. Najczęściej korzysta z takich aplikacji, jak: Facebook (ze względu komunikację w grupie na roku studiów), Instagram (żeby wiedzieć, co się dzieje u jej znajomych i być na bieżaco), Messenger (do komunikacji).

Studentka nie czuje się twórca w internecie, jak już wspomniała wcześniej, tylko przeglada co media społecznościowe jej proponują. Fotografuje telefonem komórkowym wydarzenia, w których bierze udziat $i$ udostępnia je głównie w relacjach (zdjęcia te znikaja po 24h), by jak sama przyznata pótżartem „koleżanki mogły mi zazdrościć" lub dlatego że robia to też inni. W swojej galerii posiada aktualnie ok. 1600 zdjęć.

Kobieta nie ma świadomości wykorzystywania jej danych w internecie i nie chroni ich, ponieważ nie widzi nic złego w podaniu swojego imienia czy nazwiska. Jest przeciwna plagiatowi. Uważa, że zawsze trzeba pytać o zgodę autora, jeśli chcemy wykorzystać jego pracę. Sama nie udostępnia takich treści, chyba że używa ich w pracach pisemnych (np. na rzecz pracy na zajęcia), wtedy oznacza je cytatem, przypisem i umieszcza w bibliografii. Przyznaje, że korzysta z nielegalnych źródet, bo nie musi za nie ptacić.

Natalia twierdzi, że używa mediów elektronicznych do zdobywania wiedzy o kulturze, a najbardziej interesuje ja kino i teatr. Nie przyznaje, w jaki sposób owa wiedze zdobywa, jednak nieoficjalnie wiem, że przeglada często "pudelka". Grupy fandomowe sa jej obojętne, a sama do żadnej nie należy. Nie wzoruje się na zachowaniach kreowanych $w$ sieci, jednak w przypadku wydarzenia "czarny poniedziałek" polegającego na ubraniu się kobiet na czarno w ramach protestu dotyczacego aborcji, sama ubrała się tego dnia na czarno popierając jednocześnie akcję.

Jako kryteria wtączenia kogoś do znajomych, Natalia uważa, że musi taka osobe dobrze znać. Przyznaje, że wcześniej dodawała osoby nawet jak tylko kojarzyła je „z widzenia". Teraz jest bardziej restrykcyjna. Jeśli chodzi o wyłaczenie z grona znajomych, Natalia zwraca uwage na osoby tworzace "spam". Wszystkie osoby udostępniające nieinteresujące ją treści lub proszące nadmiernie o pomoc w klikaniu "lajków", udostępnianiu dalej, sa przez nią usuwane. Studentka lubi używać emotikonek i często robi to, 
choć nieprzesadnie. Jej stosunek do lajkowania jest dość luźny. Robi to tylko, gdy ktoś ja poprosi lub najbliższym osobom "przy okazji", kiedy przeglada ich zdjęcia i zauważy coś nowego. Jak sama mówi, "robię to, żeby nie robić im przykrości”.

Informacje dostęne $w$ mediach elektronicznych Natalia traktuje z dystansem, jednak jako źródto weryfikacji ich traktuje swoja mamę. Przyznaje, że czasem zdarzy jej się uwierzyć w plotki, jednak nie jest to często.

Jeżeli chodzi o zagrożenia, na jakie zwraca uwage, sa to głównie: naruszanie praw autorskich, zjawisko hejtu i cyberprzemocy, uzależnienie, dekoncentracja, czy łatwo dostępna pornografia dla młodych. Jeśli zaś chodzi o korzyści, Natalia mówi o wygodności i łatwości dostępu (wszystko jest pod ręka i szybko można znaleźć potrzebna informacje), można robić optaty bez stania w kolejkach oraz wspomina o udogodnieniu dla osób starszych, które moga zrobić zakupy online.

Treść wypowiedzi zarejestrowanych przez studentów w trakcie wywiadów została poddana analizie jakościowej. Zobaczmy zatem, jak kształtują się codzienne doświadczenia i praktyki medialne młodych ludzi oraz jak młode pokolenie wykorzystuje media elektroniczne do komunikacji oraz uczestnictwa w kulturze.

\section{Korzystanie z urządzeń elektronicznych}

\section{i typy aktywności w mediach społecznościowych}

Analiza poszczególnych wypowiedzi wykazała, że wszystkie badane osoby korzystają z cyfrowych urządzeń mobilnych, czyli smartfonów, rzadziej laptopów. W Sieci spędzają około trzech-czterech godzin dzienne. Używają rozmaitych aplikacji, ale najczęściej wybierają takie, jak: Facebook, Instagram, Messenger, Snapchat, YouTube, jedna osoba korzysta z platformy Netflix. 23-letni mężczyzna o wykształceniu zawodowym, mieszkający na wsi, najczęściej wybiera następujące aplikacje i portale: Skype, Viber, Whats, Endomondo (pomiar osiągnięć sportowych), Google Pay (płatność telefonem), Yanosik (GPS), bankowości internetowej. Oprócz tego używa menedżera stron, portali społecznościowych, poczty elektronicznej, stron z prognozą pogody i robi zakupy przez Internet. Kilka osób przyznaje się do uzależnienia od używania smartfona, jednakże jedna z nich stwierdziła, że nie byłoby dla niej problemem brak dostępu do mediów społecznościowych przez kilka dni. Jedna osoba (student informatyki z małego miasta) natomiast rzadko korzysta z mediów społecznościowych (Instagram i Facebook), a smartfona używa głównie do pracy.

\section{Udostępnianie materiałów w Sieci}

Wszyscy rozmówcy używają aparatu fotograficznego w smartfonie, mają zwykle ponad tysiąc zdjęć w pamięci telefonu, które często udostępniają 
w Sieci za pośrednictwem aplikacji Instagram i Facebook, robią to w różnym celu, ale najczęściej po to, by pokazać znajomym miejsca, które odwiedzili i wydarzenia, w których uczestniczyli, aby inni też mogli skorzystać na przykład z danej oferty kulturalnej. Tylko jedna osoba deklaruje, że tego nie robi , bo nie chce, aby znajomi wiedzieli gdzie przebywa ani co robi.

\section{Tworzenie własnych treści oraz ich publikowanie w Sieci}

Połowa badanych uważa się za biernych użytkowników Sieci, bo nie tworzą ani nie publikują tam własnych materiałów, a portale i aplikacje służą im głównie do komunikacji, oglądania filmów, słuchania muzyki. Niektórzy deklarują, że czują się twórcami, bo na przykład stworzyli funpage na Facebooku czy kanał tematyczny na serwisie YouTube, gdzie udostępniają własne nagrania i filmy oraz nagrania nadesłane przez innych użytkowników. Jedna osoba w przeszłości prowadziła bloga fotograficznego, w którym opisywała swoje życie. Dwie osoby tworzą i publikują treści (zdjęcia, posty) w celach zarobkowych, jedna reklamując w ten sposób swoją działalność gospodarczą (salon pielęgnacji dla psów), druga prowadząc blog kulinarny.

\section{Prywatność w Sieci i jej ochrona}

Do ochrony własnych danych badani mieli zróżnicowany stosunek - od pełnej nonszalancji i bagatelizacji problemu, po działania służące jak najlepszej ochronie prywatności. Pojawiały się opinie: „wolę o tym nie myśleć, bo popadłabym w paranoję", czy „lepsza jest niewiedza”. Osoby dbające o bezpieczeństwo swoich danych używają odpowiednich haseł, ograniczają grono znajomych w mediach społecznościowych wyłącznie do znanych sobie osób, z ostrożnością i nieufnością podchodzą do rozmaitych profili na portalach społecznościowych, mając świadomość, że wiele z nich może być fałszywych. Starają się też nie podawać lekkomyślnie swoich danych, aby uniknąć wykorzystywania ich przez niepowołane osoby.

\section{Uczestnictwo w kulturze i jego uwarunkowania}

Badani często, mimo deklarowanych zainteresowań kulturalnych, przyznają, że nie pogłębiają swojej wiedzy za pośrednictwem mediów elektronicznych, tematycznych portali, czy serwisów internetowych. Inni mówią, że nie interesują się niczym aż tak bardzo, aby poszerzać i pogłębiać swoją wiedzę. Źródłem wiedzy na temat kultury jest dla nich przede wszystkim Facebook i YouTube. Młodzi z badanej grupy zwykle słuchają muzyki z portali streamingowych. Jedna osoba informacje o wydarzeniach kulturalnych czerpie z lokalnego radia, szczególnie te dotyczące teatru, kina i koncertów. Kolejna wyszukuje informacje na temat konkretnych imprez oraz ogląda transmisje koncertów i festiwali muzycznych w telewizji (również internetowej). Inna 
osoba rzadko sama szuka w Internecie informacji na temat wydarzeń kulturalnych, raczej korzysta z informacji wyświetlających się podczas przeglądania portali społecznościowych. Nikt nie wspomniał o serwisach upowszechniających zasoby kultury typu ninateka.pl, czy o serwisach promujących legalne jej źródła, jak na przykład legalnakultura.pl. Uczestnictwo w kulturze badanych osób można określić mianem „kultury Facebooka, YouTube'a i Instagrama" ${ }^{21}$, bo to właśnie te serwisy głównie kształtują upodobania, kierunki zainteresowań i zasoby kulturalne młodych.

\section{Problem praw autorskich $\mathrm{w}$ mediach}

Deklaracje w tej kwestii są jasne - nikt z badanych nie pochwala i nie toleruje plagiatu, zawsze oznaczają autora jeśli udostępniają jakieś treści. Większość korzysta wyłącznie z legalnych źródeł w Sieci, niektórzy przyznają jednak, że oglądają filmy i seriale na nieoficjalnych portalach.

\section{Konstruowanie tożsamości w mediach i przez media}

Stosunek badanych do budowania tożsamości w mediach był dosyć zróżnicowany. Rozmówcy mają świadomość istnienia nie tylko fałszywych kont i fałszywych tożsamości w mediach społecznościowych, ale także kreowania fikcyjnego życia na potrzeby tych mediów przez ich użytkowników. Takie działania postrzegają jako „ucieczkę od samego siebie” i postawę służącą niwelowaniu lęku przed odrzuceniem przez społeczność czy konkretną grupę. Jedni deklarowali, że posiadają pewien autorytet, czy ulubionego artystę, na którym się wzorują oraz uważają, że nie ma w tym nic złego, dopóki taka osoba nie staje się obsesją. Jedna $\mathrm{z}$ badanych przyznaje się do wzorowania się na osobach promujących na Instagramie zdrowy tryb życia oraz korzysta z porad makijażystek w serwisie YouTube. Jedna osoba stwierdziła, że nie ma w Internecie żadnego wzorca ani przykładu, bo to jest rola ojca i rodziny. Inne osoby również deklarują brak konkretnych wzorów, choć przyznają że ulegają czasem pewnym fascynacjom.

\section{Budowanie grup i wspólnot}

Podstawową wspólnotę w Sieci stanowią grupy znajomych na Facebooku i Instagramie, a "dodawanie”, "odrzucanie” i „wyrzucanie” z grona znajomych stanowi formę ich konstruowania. Przynależność do grupy znajomych

${ }^{21} \mathrm{~W}$ rankingu najpopularniejszych portali społecznościowych na świecie trzy pierwsze miejsca zajmują: Facebook (2,2 mld użytkowników), YouTube (1,8 mld), Instagram ( $800 \mathrm{mln}$ użytkowników). Zebrane przez dreamgrow.com dane dotyczą stanu na dzień 22 maja 2018 i pochodzą zarówno z informacji udostępnianych przez same serwisy, jak i narzędzi umożliwiających takie pomiary; https://socialpress.pl/2018/06/15-najpopularniejszych-portali-spolecznosciowych-na-swiecie\# [dostęp: 11.12.2018]. 
jest, w opinii badanych, wyrazem sympatii i aprobaty aktywności sieciowej danej osoby, którą można stracić na przykład przez udostępnianie obraźliwych czy nieprawdziwych postów oraz niezgodnych z oczekiwaniami i przekonaniami wzmianek na temat konkretnych osób. Badani często używają emotikonek, za pomocą których nie tylko wyrażają swoje uczucia, ale także uważają ich stosowanie za sposób na okazanie sympatii innym. Podobnie traktują tak zwane polubienia, czyli „lajki”, będące wyrazem sympatii, poparcia i wsparcia akceptowanych znajomych. Spośród badanych nikt nie przynależy do żadnego fandomu czy grupy fanowskiej, ale wielu uważa to za ważną i interesująca formę sieciowej wspólnoty, pozwalającą na poznawanie ciekawych ludzi, wymianę informacji, pomysłów, wiedzy, doświadczeń, uczestnictwo w dyskusjach, czy tworzenie fan-art'ów.

\section{Sposoby weryfikacji wiarygodności informacji dostępnych w mediach}

Badani młodzi ludzie dostępne $w$ Internecie informacje i wiadomości starają się porównywać $\mathrm{z}$ tymi na innych portalach lub $\mathrm{w}$ innych mediach - prasie czy radiu, deklarując, że podchodzą do nich z dystansem, choć czasem zdarza im się wierzyć w plotki. Jedna osoba, która wszelkie informacje zdobywa za pośrednictwem YouTube'a nie sprawdza ich wiarygodności samodzielnie, a tylko poprzez opinie znajomych, bądź inne komentarze dostępne $\mathrm{w}$ tym serwisie. Rozmówcy nie wspominają o takich problemach jak fake newsy, farmy troli, czy używanie internetowych botów do manipulacji informacją i tworzenia tak zwanych wpisów automatycznych, na przykład w kampaniach politycznych.

\section{Zagrożenia i korzyści wynikające z korzystania z mediów elektronicznych}

Główne zagrożenia w opinii badanych, to rozmaite formy oszustwa, naruszanie praw autorskich, zjawisko hejtu i cyberprzemocy, uzależnienie, łatwo dostępna pornografia dla młodych. Natomiast najczęściej zauważane korzyści, to łatwość komunikacji z innymi ludźmi, szeroki dostęp do informacji, rozrywki, edukacji, dostępność usług online (bankowość, zakupy). Badani nie skupiali się na szkodliwości i krytyce medialnych treści, traktując zagrożenia z nich płynące tak samo, jak wszystkie inne, których należy unikać, aby chronić swoją prywatność, zdrowie i życie.

Badania przeprowadzone przez studentów stanowią jedynie skromne wprowadzenie do zagadnienia uczestnictwa w kulturze w zmieniającym się pod wpływem ekspansji mediów cyfrowych świecie. Przestrzenie kultury nie tylko się zmieniają, ale znacznie poszerzają dostępność do zasobów kultury, która staje się coraz łatwiejsza, co nie znaczy że powszechna. Świado- 
mość młodego pokolenia skolonizowana jest przez globalne media społecznościowe i udostępniane za ich pośrednictwem treści współtworzone przez użytkowników serwisów. Młodzi mimo że mają nieograniczony dostęp do rozmaitych zasobów, nie korzystają z nich, bo często nie są świadomi ich istnienia lub po prostu nie zadają sobie trudu, żeby wyjść poza schematy utrwalonych zachowań komunikacyjnych, polegających na sprawdzaniu informacji pojawiających się na popularnych portalach i serwisach. W trakcie dyskusji podsumowującej przeprowadzone wywiady, studenci przyznawali, że wobec mnogości treści mają problem z wyszukiwaniem i selekcją tych, które są im potrzebne lub takich, na których specjalnie im zależy. Nie przejmują się jednak swoją niekompetencją czy niewiedzą i kiedy potrzebują potrzebnej informacji, często zamiast próbować odnaleźć i zweryfikować ją samodzielnie, szukają odpowiedzi (najczęściej za pośrednictwem komunikatora) wśród bardziej zorientowanych i kompetentnych znajomych. Zachowanie tego typu pokazuje, jak charakterystyczne dla tego pokolenia jest wzajemne uczenie się. Na serwisach społecznościowych youtberzy, influencerzy, pranksterzy uczą, doradzają i bawią. Dzielą się swoim doświadczeniem, służą radą jak zostać gwiazdą w Sieci, czy zdobyć kontrakt reklamowy dla swego konta w danym serwisie. Bez mediów społecznościowych i technologii mobilnych nie może obyć się dzisiaj również promocja kultury i sztuki. Wykorzystanie mediów społecznościowych i efektywna komunikacja na Facebooku, Instagramie, czy Snapchacie pozwala na dostęp w krótkim czasie do szerokiego grona odbiorców, co umożliwia rozwój kariery artystycznej, czy skuteczną promocję danej instytucji kultury.

W epoce cyfrowej nadal jest potrzebna edukacja medialna, bo spotykamy się z nowymi problemami, przede wszystkim inną od dotychczasowej rolą aktywnego udziału w kulturze medialnej, która uwzględnia zaangażowanie w tworzenie nowych technologii, marek, franczyz oraz udział mediów społecznościowych w życiu codziennym. Młodzi ludzie coraz więcej czasu spędzają przed ekranami i aktywnie współtworzą kulturę mediów. Nie tylko są odbiorcami obrazów i komunikatów medialnych, ale również ich twórcami oraz członkami rozmaitych grup fanowskich. Istnieje więc potrzeba uaktualniania badań na temat tego, w jaki sposób odbiorcy mówią o mediach oraz jak ich używają. Badania takie wydają się również niezbędne w procesie budowania nowej koncepcji edukacji medialnej, uwzględniającej zdobywanie umiejętności nawigowania w zasobach kultury. Można mieć nadzieję, że poznanie stosunku rówieśników do praktyk medialnych i refleksja nad uzyskanymi wynikami badań pomoże przyszłym animatorom kultury w projektowaniu działań animacyjnych i edukacyjnych w przestrzeni kultury medialnej i mediów społecznościowych. 


\section{Zakończenie. Kultura przyszłości?}

Analiza wywiadów skłania do refleksji nad kompetencjami medialnymi młodych ludzi urodzonych i wychowanych w epoce dynamicznego rozwoju technologii cyfrowych. Posiadają oni podstawowe kompetencje, które powinny charakteryzować świadomego i aktywnego odbiorcę komunikatów medialnych oraz służyć poznawaniu kultury i aktywnemu w niej uczestnictwu. Młodzi ludzie umieją posługiwać się nowymi technologiami, potrafią wyszukiwać informacje i krytycznie się do nich ustosunkowywać. Samodzielnie uczą się posługiwania nowymi narzędziami oraz sami je tworzą, wykorzystują urządzenia mobilne do społecznego komunikowania się, wymiany informacji i doświadczeń, tworzą własne komunikaty medialne lub przekształcają te już istniejące. Wykorzystują media do pracy zarobkowej oraz jako przestrzeń prezentacji własnej twórczości. Traktują Sieć jako wspólnotę towarzyską skupioną wokół mediów społecznościowych, które są dla nich podstawowym źródłem wiedzy o świecie, kulturze i społeczeństwie. Żyą w hermetycznym środowisku medialnym, przekonani, że mają nad swoimi działaniami, opiniami, poglądami kontrolę. Kompulsywne korzystanie z mediów społecznościowych nie jest dla nich przejawem uzależnienia, a jedynie rodzajem przyzwyczajenia. Cechuje ich często brak refleksyjności w odniesieniu do własnej aktywności medialnej i powierzchowność w korzystaniu z zasobów kultury, które utożsamiają z treściami służącymi przede wszystkim rozrywce. Młode pokolenie uczestniczy w procesie tworzenia wspólnotowej przestrzeni medialnej kultury, na którą składają się rozmaite treści - samodzielnie wyszukane lub stworzone, wymienione, przetworzone. Tak konstruowana kultura skłania jej indywidualnych uczestników do kreatywności, autoekspresji, zdobywania nowych umiejętności oraz tworzenia grup i wspólnot. Kultura mediów społecznościowych jest faktem, ponad dwa miliardy użytkowników Facebooka na świecie tworzy przestrzeń mobilnej kultury przyszłości, której kształtu i zasięgu nie jesteśmy w stanie sobie na razie wyobrazić.

\section{BIBLIOGRAFIA}

Broch A., Smartfon w klasie: od zabawki do narzędzia edukacyjnego, Studia Edukacyjne, 2018, 48.

Creswell J.W., Projektowanie badań naukowych, Metody jakościowe, ilościowe i mieszane, przekł. J. Gilewicz, Kraków 2013.

Edukacja medialna jako kapitał społeczno-kulturowy w społeczeństwach wiedzy. Wnioski i rekomendacje po I Kongresie Edukacji Medialnej (Kraków 25-26 września 2014), [w:] Edu- 
kacja medialna w dobie wspótczesnych zmian kulturowych, społecznych $i$ technologicznych, red. A. Ogonowska, G. Ptaszek, Kraków 2015.

Fatyga B., Rekonstrukcja sensu kategorii uczestnictwo w kulturze, [w:] Praktyki kulturalne Polaków, red. R. Drozdowski, B. Fatyga, M. Filiciak, M. Krajewski, T. Szlendak, Torun 2014. Filiciak M., Danilewicz M., Halawa M., Mazurek P., Nowotny A., Młodzi i media. Nowe media a uczestnictwo w kulturze. Raport Centrum Badań nad Kulturą Popularną SWPS, Warszawa 2010.

Fiske J., Zrozumieć kulturę popularna, Kraków 2010.

https:/ / socialpress.pl/2018/06/15-najpopularniejszych-portali-spolecznosciowych -na-swiecie\# [dostęp: 11.12.2018].

Jakubowski W., Aktywność kulturalna w świecie popkultury, Studia Edukacyjne, 2010, 11.

Krajewski M., W kierunku relacyjnej koncepcji uczestnictwa w kulturze, Kultura i Społeczeństwo, 2013, 1.

Krajewski M., Uczestnictwo w kulturze, [w:] Praktyki kulturalne Polaków, red. R. Drozdowski, B. Fatyga, M. Filiciak, M. Krajewski, T. Szlendak, Torun 2014.

Lisowska-Magdziarz M., Edukacja medialna w kontekście praktyk twórczych i interpretacyjnych, [w:] Edukacja medialna w dobie wspótczesnych zmian kulturowych, społecznych i technologicznych, red. A. Ogonowska, G. Ptaszek, Kraków 2015.

Ogonowska A., Edukacja medialna. Klucz do rozumienia społecznej rzeczywistości, Kraków 2003.

Ogonowska A., Telewizja w edukacji medialnej, Kraków 2009.

Ogonowska A., Współczesna edukacja medialna: teoria i rzeczywistość, Kraków 2013.

Poyntz S.R., Pedri J., Youth and Media Culture, Online Publication Date Jan, Oxford 2018; http:/ / oxfordre.com/education/view/10.1093/acrefore/9780190264093.001.0001/ acrefore-9780190264093-e-75 [dostęp: 10.12.2018].

Smartfon jako osobiste narzędzie edukacyjne ucznia. Analiza i rekomendacje ekspertów Sieci Edukacji Cyfrowej KOMET@, Warszawa 2018; http://presscafe.eu/assets/img/smartfon_w_szkole.pdf [dostęp: 03.12.2018)]. 